\title{
Scope of Business Process Reengineering in Public Sector Undertakings
}

\author{
George Mathew ${ }^{1}$, Sulphey M. M. ${ }^{2} \&$ Rajasekar S. ${ }^{3}$ \\ ${ }^{1}$ Anna University, Chennai, India \\ ${ }^{2}$ TKM Institute of Management, Kollam, India \\ ${ }^{3}$ Akshaya Institute of Management Studies, Coimbatore, India \\ Correspondence: George Mathew, Vettathu, RG-85 Pongummoodu, Medical College P.O., Trivandrum-695011, \\ Kerala, India. Tel: 471-255-1755, E-mail: georgevettathu@gmail.com
}

Received: August 10, 2015 Accepted: August 28, 2015 Online Published: September 8, 2015

doi:10.5539/ass.v11n26p129 URL: http://dx.doi.org/10.5539/ass.v11n26p129

\begin{abstract}
Business Process Reengineering (BPR) is a managerial tool used for bringing in drastic performance improvements in organizations. Towards this advanced techniques like Business Process Management (BPM) and Knowledge Management are employed the world over. In India, many Public Sector Undertakings (PSUs) were recently closed down and still more are on the verge of closure due to various reasons. Despite the utility of BPR in improving performance, Indian PSUs are yet to effectively use this tool. Data pertaining to 41 State PSUs (SPSUs) and two Central PSUs (CPSUs) in the State of Kerala were considered for the present study. The performance for the last 12 years and the factors responsible for poor performance were analyzed. The performance of most of the PSUs analyzed was found to be below satisfactory levels. This suggests the need for employing scientific tools like BPR to bring in drastic performance improvement. The study identified 12 factors that could contribute towards drastic performance improvement. An average improvement of 57.5 per cent was found to be possible in each of the 12 factors identified. The findings of the study have significant bearing on poorly performing PSUs in a developing country like India. The study also contributes substantially towards theory building, since it has identified certain additional factors of performance improvement.
\end{abstract}

Keywords: business process reengineering, business process management, process improvement, factors of performance improvements, public sector

\section{Introduction}

There is a definite need for business organizations to improve performance by incorporating innovative ideas and the latest managerial techniques. In this competitive world businesses need to be efficient and effective to stay competitive. Organizations will find it difficult to survive unless they adapt to the fast changing business environment. This situation holds true for all forms of organization, with Public Sector Undertakings (PSUs) being no exception. In the case of adoption of modern managerial techniques, PSUs are found to lag behind, thus holding themselves at a disadvantage. In spite of poor performance of Indian PSUs, there has been no marked attempt towards implementation of BPR. Since there are possibilities for drastic improvement in performance of PSUs, it is of paramount importance to try implementation of BPR. Successful BPR implementation will definitely reestablish the premier role of PSUs in the development of the economy. The main question here is the suitability of BPR as a potent solution for the revival of PSUs.

According to Goksoy, Ozsoy and Vayvay (2012) if a firm wants to survive in today's hypercompetitive environment it needs to bring in moderate change every year and undergo a major change almost every fifth year. Cost and quality as the determinants of success have given way to flexibility and responsiveness. This necessitates a paradigm shift to process management. BPR is "the role that process management can play in creating sustainable competitive advantage" (Herzog, Polajnar, \& Tonchia, 2007). This situation holds good for all forms of organization, including PSUs.

PSUs have a paramount role in the economic development of countries like India. However, performance wise, there is much to be done in the case of PSUs. In 2005-2006, 157 profit making enterprises earned a total net profit of Rs. 76240 crores and 58 loss making units incurred a total loss of Rs. 5952 crores. The Economic 
Review 2010 showed that many PSUs run at a huge loss. Loss making units rose by 36 per cent and loss amount by 375 percent during 2012-13. Recognizing the role of PSUs, Government of India has evolved a number of strategies for reviving and strengthening them. These strategies include revival of PSUs through the process of Bureau of Industrial and Financial Reconstruction (BIFR); financial restructuring wherever appropriate and formation of joint ventures with partners capable of providing technical, financial and marketing inputs. Certain other measures like infusion of fresh funds; organizational and business restructuring; human resources development including manpower rationalization through approved Voluntary Retirement Scheme (VRS); improved marketing strategies; modernization and technological innovations; and cost control measures were also invoked.

The State of Kerala has a significant number of State PSUs (SPSUs), which employed 132677 personnel during 2012-13. Government of Kerala (2005) however, laments that SPSUs "in the manufacturing sector have been plagued by poor standards of Governance". Reasons adduced are: diffused nature of ownership, lack of synchronization of critical state sponsored interventions for improving its performance, conflicting objectives advocated by trade unions, inadequate incentives for competent personnel, delayed decision making, redundancy of manpower and improper person-task fit, outdated technology and unviable processes. Many SPSUs were closed down due to their inability to survive even after revival trial under the supervision of BIFR of Govt. of India. However, some sick units have been revived after implementing revival package under the supervision of BIFR. There is urgent need for implementing changes and reforms as the number of PSUs that face the threat of closure due to accumulated losses has increased. Mathew (1997) evaluated the performance of state PSUs in the manufacturing Sector of Kerala and found that out of the 47 manufacturing undertakings, only 18 enterprises made profits during 1992-93; while 29 made losses. The manufacturing PSUs incurred a net loss of Rs. 1183.06 lakhs during the same period. A comparison of the performance of State PSUs at five stages from 1994-95 to 2012-13 is given in Table 1.

Table 1. Performance of Government Companies in Kerala (Amount in Rs. Crores)

\begin{tabular}{cccccc}
\hline Indicators & $1994-95$ & $2001-02$ & $2005-06$ & $2010-11$ & $2012-13$ \\
\hline No. of Companies & 94 & 98 & 95 & 83 & 85 \\
Employment & 71553 & 61087 & 60724 & 76179 & 76364 \\
Capital Invested & 1716 & 4082 & 7175 & 8145 & 10725 \\
No. of Profit Making Units & 41 & 35 & 29 & 53 & 48 \\
Net Profit & 56.96 & -16.34 & -23.4 & 675.41 & 348.65 \\
\hline
\end{tabular}

Source: Government of Kerala (1995 to 2013)

The table portrays a poor record of performance and calls for a detailed study on the reasons of performance variation and scope of performance improvement in Kerala PSUs.

\subsection{Problem Statement}

BPR is a managerial tool that is used for drastic performance improvements in organizations for the last two and half decades, particularly in the industrialized western world. At present, the western world is ahead with use of newer techniques like BPM and Knowledge Management. Use of BPR or related techniques is limited in India. A poor and highly fluctuating trend in performance is evident on assessing data regarding Public Sector Enterprises (Government of Kerala, 2002 to 2013) for 2001-02 to 2012-13. Until now, Kerala has no recorded BPR initiatives. This motivated a detailed analysis on the scope of BPR as a solution for the revival of these poor performing organizations. The objectives identified for the study are:

1. Evaluating the performance of PSUs in Kerala

2. Identifying the factors of performance improvement in PSUs in Kerala

3. Measuring the possible improvements in performance with BPR

4. Comparison of possible performance improvements in SPSUs with that of CPSUs in Kerala with implementation of BPR.

\subsection{Literature Review}

Present state of management techniques and technologies for performance improvements is the result of the convergence of many managerial techniques developed and modified for many years. Some of the earlier 
contributions are; principle of division of labor by Adam Smith (1776), Principles of Scientific Management by, Frederick W. Taylor (1911), Mass production techniques introduced by Henry Ford (1913), etc. Technologies used for improvement of organizational performance, though known by different names, are similar in certain aspects. The suitability of these techniques depends on the situation. Since BPR is a strategy for drastic improvement, the possibilities of drastic improvements in performance as PSUs in the Indian context were examined. BPR in its crude form was in existence even in the days of Fredrick Taylor, Henri Fayol, etc. (Kondareddy, 1998; Kuwaiti, 2000). It was developed into a new managerial technique called BPR during 1990 by Hammer \& Champy. During the same time, Davenport and Short (1990) developed the concept of Business Process Redesign with the similar concept of BPR. In the initial stage, BPR was mainly adopted by US based firms for bringing radical change in the business process as a replacement of the Japanese approach of TQM (Hammer \& Stanton, 1995). To Hammer \& Champy (1993) BPR is "the fundamental rethinking and radical redesign of business processes to achieve dramatic improvements in critical, contemporary measures of performance, such as cost, quality, service, and speed". BPM, according to Elzinga, Horak, Lee \& Brunber (1995) "is a systematic structured approach to analyze, improve, control and manage processes with the aim of improving the quality of products and services". In the modern context the redesign of processes relies on the use of information technology (IT). Objectives of Business Process Redesign are Cost Reduction, Time Reduction; Output Quality, and Quality of work life/ learning/ empowerment (Davenport \& Short, 1990), pressure of survival, close of competitive gaps, superior performance standards (Al-Mashari, Irani, \& Zairi, 2001). BPR initiatives usually aim to integrate separate functional tasks into complete cross-functional processes. Reengineering utilizes components of several management tools and concepts such as Systems Engineering, TQM, Continuous Improvement, Bench marking, Activity Based Costing, Customer Satisfaction Management, Cross functional team building and widespread use of IT (Kondareddy, 1998). A few identical concepts almost used as synonyms of BPR are: Business Process Redesign (Davenport \& Short, 1990), Business Process Improvement (Hammer \& Champy, 2001; Siha \& Saad, 2008), and Business Process Management (BPM) (Elzinga et al., 1995). Hammer (2002) defines Process Improvement as "A structured approach to performance improvement that centers on the disciplined design and careful execution of a company's end-to-end business process."

Kim \& Kim (1997) developed a new methodology called Enterprise Process Reverse Engineering (EPRE) for supporting the redesign phase of BPR. Despite differences in terminologies their essence is process improvement. BPR employs many managerial tools and techniques. Goksoy et al. (2012), Radhakrishnan \& Balasubramanian (2008) and others pursuing this line of thinking call them as BPR enablers.

Use of IT in BPR for improving the process efficiency has been witnessed by (Attaran, 2004; Bhatt \& Troutt, 2005; etc.). Six-Sigma prescribes a rigorous structured approach to improve product quality (Goel \& Chen, 2008); raise efficiency; reduce costs or expenses, process times; and the resultant maximization of profits and customer satisfaction (Chung, Hsu, \& Yen, 2008). Involving employees in every step of the production process is employee empowerment. The performance benchmarking model can be based on any defined foundation including quality, flexibility, agility, profitability or market share. It can be used to determine the performance gaps between itself and a pre-defined level of performance or its strategic competitors (Yung \& Chan, 2003). Mazany (1995) refer to Just-In-Time (JIT) broadly as the philosophy that encourages an organization to remove all types of waste principally that associated with time and materials. The Taguchi concept of Product and process optimization can be applied in 'system design' and 'parameter design' phases of a system for reducing cost (Garzon, 2000). Agile Manufacturing enables businesses to be flexible and lean. The main concept of lean thinking is the elimination of seven types of waste: (1) Overproduction; (2) Waiting; (3) Unnecessary transportation; (4) Inappropriate processing; (5) Unnecessary inventory; (6) Unnecessary movement and (7) Defective products (Womack \& Jones, 1996).

Many a research reported benefits of BPR implementation. Bell Atlantic Telephone was able to cut cycle time from 15 to 3 days, labour cost from eighty eight millions to six millions (Ranganathan \& Dhaliwal, 2001). Paper, Rodger \& Pendharker (2001) demonstrated a BPR case of reducing defect rate by $70 \%$, customer rejects by $57 \%$, cycle time on parts by $72 \%$, inventory investment by $46 \%$, and customer lead time by $70 \%$. Overall improvement in this case came to $63 \%$. Housing Development Board in Singapore, achieved dramatic improvements in; Customer Service (87\%), Lease \& Tenancy Services (58.4\%), Financial Services (66.1\%), Maintenance/Renovation Services (66.7\%), General Administration(34\%). The average improvements in this case were 62.4\% (Thong, Yap, \& Seah, 2000). Altinkemer, Ozcelik, \& Ozdemir (2011) reported that there are performance improvements in manufacturing and operations, accounting and finance, labor productivity, inventory turnover and IT by the implementation of BPR even though there is a slight reduction during the initial 
stages of project implementation.

Promotional role of PSUs in the development scenario of India is well acknowledged. Until the early 1990s (Kanungo, Sadavarti \& Srinivas, 2001), it helped industrialization, generation of employment, and dispersal of industries to different parts of the country (Antony, 1992). While the global recession of 2008 rattled the economies of most of the developed countries, Indian economy remained mostly unaffected on account of the special role that PSUs enact (Kareem, 2011). However, the maladies afflicting Indian PSUs leading to low capacity utilization has been subjected to criticism. Extending this argument to the component level (State level) Mathew, Sulphey \& Rajasekar (2014) established that most of the SPSUs in Kerala are poor performers. Reforms are needed to strengthen PSUs that are poorly organized, with irrational decision-making processes, staff mismanaged, weak accountability, poorly designed public programs and poorly delivered public services (Schacter, 2000). Aside from the benefits of process reengineering, it provides considerable improvement in efficiency and effectiveness enabling the organization to earn for itself the envious status of a vibrant, dynamic and progressive concern (Zaheer, Rehman, \& Saif, 2008). In their study: "Organizational Change Effectiveness in an Indian Public Sector", Nandan \&Verma (2013), identified four change outcomes, namely enhancement in employee involvement, improvement in employee performance management, improvement in work environment, and improved organizational systems. Rahimi (1996) argues that it is high time that PSUs in India go for BPR as more than 70 per cent of large corporations, world over, have indulged in BPR, by 1996. Thong et al. (2000), Macintosh (2003), Rinaldi, Montanari and Bottani (2015) bring to light the similarities and differences in implementing BPR in Private sector and public sector. PSUs are marked with restrictions in providing resources of BPR, greater levels of consultations and consensus among employees. Still there are greater potentials for significant improvement through BPR (Rinaldi et al., 2015).

\section{Methodology}

Kerala has at present 93 SPSUs grouped under 13 sectors. However, the population of the present study is limited to 41 PSUs under the administrative control of Department of Industries, Government of Kerala. Initially, the financial performance of these 41 units was analyzed, for which data was collected from the Review of Public Enterprises published by Bureau of Public Enterprises, Govt. of Kerala (Government of Kerala, 1995 to 2013), for the years from 2001-02 to 2012-13. The tools of Net Profit, Net Profit Ratio (NPR), Return on Capital Employed (ROCE) and Altman's revised Z-Score Model (Altman, Haldeman, \& Narayanan, 1977), were used in order to understand the financial performance. To compare the performance of SPSUs in Kerala with that of CPSUs, two organizations - one Heavy Machine Company and a Health Care Company were selected. The data of CPSUs was taken from the company's annual reports.

Next the possibility of performance improvement was examined. For this, six manufacturing organizations from the above 41 PSUs were identified by judgment sampling. The SPSUs selected are:
1. Keltron Component Complex Ltd.
2. Keltron Electro Ceramics Ltd.
3. Keltron Manvila
4. Kerala Automobiles
5. Kerala Ceramics
6. United Electricals

12 performance improvement factors were identified through various methods including literature survey, a preliminary study through discussions with employees at various levels and trade union leaders, and observation by the researcher, verifying company records and procedures. 24 years of experience of one of the researchers in one of the PSUs under study and a considerable duration in teaching in management subjects of all the researchers benefited in identifying major performance improvement factors applicable to these PSUs. A questionnaire having 83 domains pertaining to the 12 factors was developed. Questionnaire was administered among the executives at different levels, as it is they who know the business well. Five point interval scale is used to assess possible performance improvement (percentage terms) as given in Table 2.

For each domain the response could be one of the five options, with each option having a predetermined score. The scores stand in a linear fashion to represent a range of values. The values 5, 4, 3, 2, and 1 are used in ordinal sense (but can be treated as interval scale as it represents interval values), to represent "Very High", "High", "Moderate", " Mild" and "Less" possibilities. But these scores also serve as the mid value in the range of $20 \%$ of the possible performance improvement. Naturally, 1 stands for $10 \%, 2$ for $30 \%, 3$ for $50 \%, 4$ for $70 \%$ of 
improvements, and so on. The decimal values also can be interpreted similarly.

Table 2. Five point interval scale in the questionnaire

\begin{tabular}{lcl}
\hline Options & Score & Possible Improvement \\
\hline Very High Possibility & 5 & $80 \%-100 \%$ \\
High Possibility & 4 & $60 \%-80 \%$ \\
Moderate Possibility & 3 & $40 \%-60 \%$ \\
Mild Possibility & 2 & $20 \%-40 \%$ \\
Less Possibility & 1 & $0 \%-20 \%$ \\
\hline
\end{tabular}

Data was analyzed using descriptive statistics and t-test. Correlation was done to know the relation between various factors of performance improvements. Comparison of possible performance improvements between State and Central PSUs was also carried out.

\section{Results}

The study was done in two stages. The first involved analyzing the performance of PSUs in Kerala, and second the possible performance improvements in the PSUs were measured.

\subsection{Performance of PSUs in Kerala}

The performance of 41 PSUs were analyzed using different financial performance indicators, namely, Net profit, NPR, ROCE and Altman's Z-score, for a period of 12 years from 2001-02 to 2011-12. Summary of performance indicators are given in Table 3.

Table 3. Summary of Performance Indicators of 41 PSUs in Kerala

\begin{tabular}{|c|c|c|c|c|c|}
\hline \multirow{2}{*}{$\begin{array}{l}\text { Sl. } \\
\text { No. }\end{array}$} & \multirow[b]{2}{*}{ Company } & \multicolumn{4}{|c|}{ Mean Values of Performance Indicators } \\
\hline & & $\begin{array}{c}\text { Profit } \\
\text { Rs. lakhs }\end{array}$ & NPR & ROC & $\begin{array}{l}\text { Altman's } \\
\text { Z-Score }\end{array}$ \\
\hline 1 & The Kerala Minerals and Metals Ltd. & 6356.17 & 14.31 & 12.85 & 1.32 \\
\hline 2 & Kerala State Drugs and Pharmaceuticals Ltd. & $(354.82)$ & $(964.20)$ & $(5.59)$ & $(0.17)$ \\
\hline 3 & Malabar Cements Ltd. & 2285.68 & 8.54 & 11.60 & 1.89 \\
\hline 4 & The Travancore Cements Ltd. & $(241.67)$ & $(9.27)$ & $(29.42)$ & 1.28 \\
\hline 5 & Travancore Cochin Chemicals Ltd. & $(157.58)$ & $(1.70)$ & $(1.60)$ & 0.79 \\
\hline 6 & Travancore Titanium Products Ltd. & 293.08 & 0.78 & $(0.02)$ & 0.94 \\
\hline 7 & Kerala State Mineral Development Corporation Ltd. & $(12.61)$ & $(0.19)$ & $(2.31)$ & 0.63 \\
\hline 8 & Kerala Ceramics Ltd. & $(134.94)$ & $(33.86)$ & $(4.67)$ & $(0.00)$ \\
\hline 9 & Kerala Clays and Ceramics Ltd. & 117.97 & 24.39 & 21.60 & 1.92 \\
\hline 10 & Kerala State Industrial Development Corporation Ltd. & 2399.22 & 83.63 & 5.30 & 0.99 \\
\hline 11 & Kerala State Industrial Enterprises Ltd. & 453.13 & 31.81 & 25.19 & 1.50 \\
\hline 12 & Kerala Small Industries Development Corporation Ltd. & 14.71 & $(1.09)$ & $(4.73)$ & 0.85 \\
\hline 13 & Kerala Industrial Infrastructure Development Corporation & 1096.03 & 74.76 & 2.49 & 0.66 \\
\hline 14 & Kerala Electrical and Alied Engineering Company Ltd. & $(187.78)$ & $(5.81)$ & $(0.20)$ & 1.10 \\
\hline 15 & United Electrical Industries Ltd. & $(203.60)$ & $(37.09)$ & $(15.95)$ & 0.75 \\
\hline 16 & Traco Cables Company Ltd. & $(408.22)$ & $(0.88)$ & $(0.90)$ & 0.77 \\
\hline 17 & Transformers and Electricals Kerala Ltd. & 1761.25 & 7.04 & 15.78 & 1.78 \\
\hline 18 & Kerala State Electronics Development Corporation Ltd. & $(1371.60)$ & 7.19 & 2.01 & 0.37 \\
\hline 19 & Keltron Electro Ceramics Ltd. & $(6.87)$ & $(5.28)$ & $(1.84)$ & 0.92 \\
\hline
\end{tabular}




\begin{tabular}{|c|c|c|c|c|c|}
\hline 20 & Keltron Component Complex Ltd. & $(216.93)$ & $(7.17)$ & $(10.24)$ & 0.62 \\
\hline 21 & Keltron Crystals Ltd & (151.94) & $(222.86)$ & $(11.57)$ & $(0.41)$ \\
\hline 22 & Keltron Mangetics Ltd & $(1.81)$ & $(5.94)$ & $(2.61)$ & 0.53 \\
\hline 23 & Keltron Resistors Ltd & $(33.10)$ & 4.12 & 3.14 & 0.58 \\
\hline 24 & The Metal Industries Ltd. & $(2.96)$ & $(4.62)$ & $(2.54)$ & 1.42 \\
\hline 25 & Steel Complex Ltd. & $(270.82)$ & $(38.21)$ & $(25.51)$ & 0.43 \\
\hline 26 & Steel Industries Kerala Ltd & $(183.83)$ & $(13.50)$ & $(1.76)$ & 0.24 \\
\hline 27 & Kerala Automobiles Ltd. & $(160.10)$ & $(16.77)$ & $(25.16)$ & 1.40 \\
\hline 28 & Steel and Industrial Forgings Ltd. & 368.92 & 7.62 & 13.37 & 1.83 \\
\hline 29 & Autokast Ltd. & $(360.30)$ & $(32.50)$ & $(0.56)$ & $(0.10)$ \\
\hline 30 & Forest Industries (Travancore) Ltd. & 23.30 & 3.27 & 5.34 & 1.18 \\
\hline 31 & Kerala Garments Limited & $(58.82)$ & $(2326.59)$ & $(34.58)$ & $(0.74)$ \\
\hline 32 & Kerala State Textile corporation Ltd. & $(536.98)$ & $(11.91)$ & $(6.78)$ & 0.38 \\
\hline 33 & Sitaram Textiles Ltd. & $(151.94)$ & $(23.66)$ & $(4.58)$ & 0.00 \\
\hline 34 & Foam Matting (India) Limited & $(41.34)$ & $(11.38)$ & $(6.02)$ & 0.79 \\
\hline 35 & Handicrafts Development Corporation (Kerala) Ltd. & $(40.66)$ & $(9.75)$ & $(5.16)$ & 0.41 \\
\hline 36 & Kerala State Bamboo Corporation Ltd. & $(143.15)$ & $(18.46)$ & $(10.70)$ & 0.50 \\
\hline 37 & Kerala State Handloom Development Corporation Ltd. & $(444.97)$ & $(26.88)$ & $(11.46)$ & 0.15 \\
\hline 38 & Kerala State Coir Corporation Ltd. & 20.48 & $(11.44)$ & $(0.87)$ & 0.76 \\
\hline 39 & Kerala State Cashew Development Corporation Ltd. & $(1549.58)$ & $(79.91)$ & $(1.19)$ & $(0.02)$ \\
\hline 40 & Kerala Artisans Development Corporation Ltd. & $(6.79)$ & $(12.16)$ & 0.92 & 0.77 \\
\hline 41 & $\begin{array}{l}\text { Kerala State Palmyrah Products Dev. \& Workers Welfare } \\
\text { Corporation Ltd. }\end{array}$ & $(5.89)$ & $(246.03)$ & $(11.39)$ & $(0.07)$ \\
\hline
\end{tabular}

Source: Compiled from Government of Kerala (1995 to 2013)

On analyzing the values in Table 3, it was seen that most of the values in the first three columns were negative, indicating that the performance of most of the PSUs were very poor. Altman score (Altman et al., 1977) also showed poor performance and most of the PSUs are in financial distress as per the rule given in Table 4.

Table 4. Altman's Z-Score model

\begin{tabular}{lll}
\hline Zone & Value of $Z$ & Interpretation \\
\hline Zone- $I$ & Less than 1.23 & Distress Zone \\
Zone-II & 1.23 to 2.9 & Grey Zone \\
Zone-III & Greater than 2.9 & Safe Zone \\
Bankruptcy Group Mean $=0.15$ & & \\
Non-Bankruptcy Group Mean $=04.14$ & & \\
\hline
\end{tabular}

Source: Zeta Analysis A New Model to Identify Bankruptcy Risk of Corporations (Altman et al., 1977)

The total net profit or loss (Rs. Lakhs) of the 41 PSUs for the period 2001-02 to 2012-13 is given in Chart 1. 


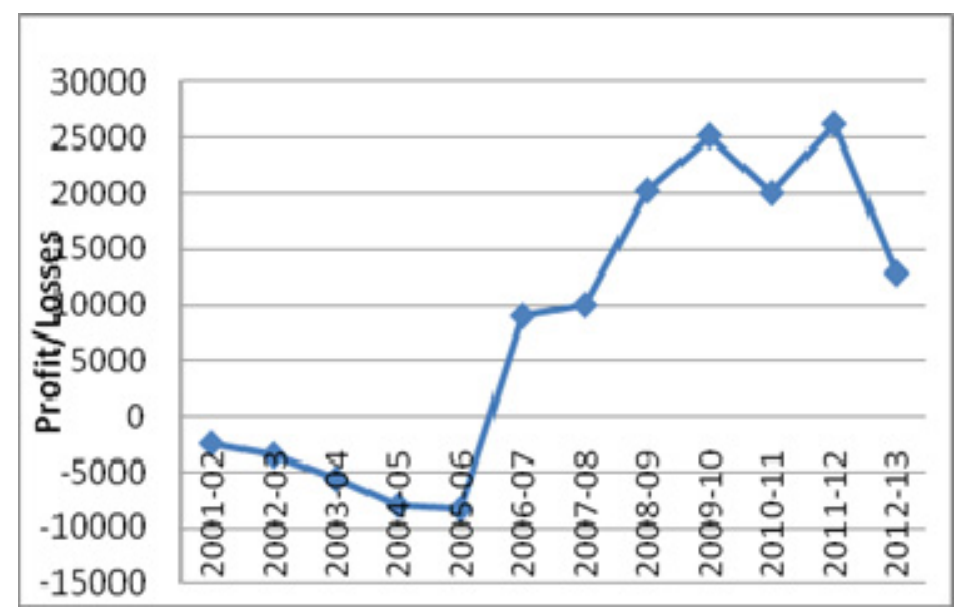

Chart 1. Net Profit / Losses of 41 SPSUs companies during 2001-02 to 2012-13

It is seen that the total net profit of 41 PSUs were negative from 2001-02 to 2005-06, resulting in a combined loss of Rs. 8385 lakhs by 2005-06. But from 2006-07 the situation changed and the PSUs started making profit; by 2011-12 the total profit earned was of Rs. 26280 Lakhs. But it slipped down again and reached a lower figure of Rs.12 871 Lakhs during 2012-13.

The performances of the selected CPSUs are presented in Charts 2 and 3.

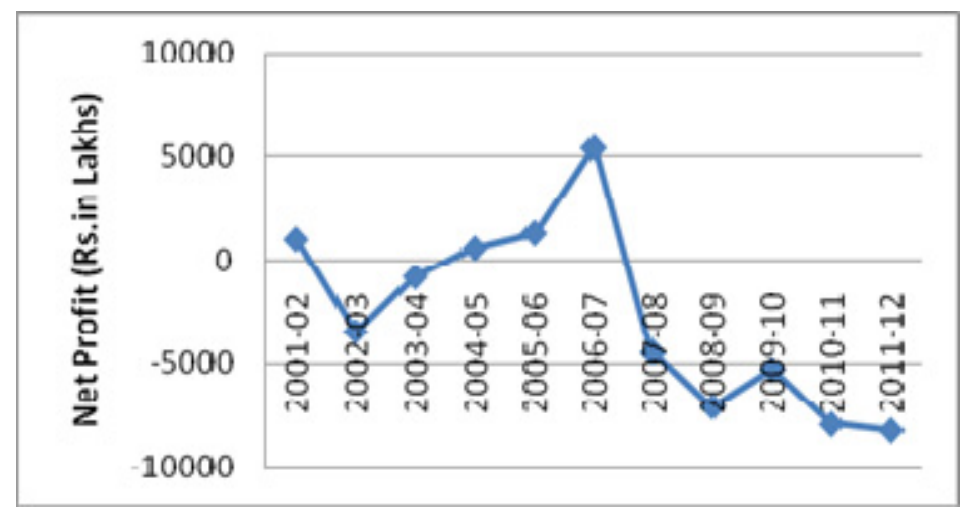

Chart 2. Net Profit / Losses (Rs. Lakhs) of Machine Tools Company

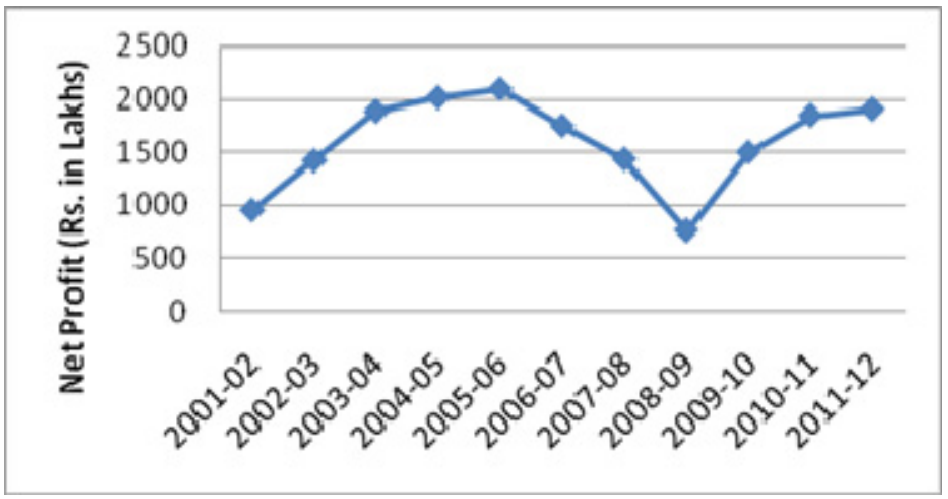

Chart 3. Net Profit / Losses (Rs. Lakhs) of Health Care Company

It can be seen that the Machine Tools Company (MTC) has been making losses for seven years and the Health 
Care Company (HCC) has been performing well and making profits for the entire period.

\subsection{Possible Performance Improvements in PSUs of Kerala}

Table 5 gives a summary of the opinion of the executives about the level of Possible Performance Improvements (PPI) in the selected SPSUs.

Table 5. Estimate of Possible Performance Improvements in SPSUs of Kerala

\begin{tabular}{lccc}
\hline Factors & Mean & Std. Deviation & Improvement \% \\
\hline Cost & 3.04 & 0.79 & 50.74 \\
Quality & 2.79 & 0.56 & 45.8 \\
Time & 3.22 & 0.79 & 54.49 \\
Delivery & 3.27 & 0.8 & 55.47 \\
Flexibility & 3.20 & 0.82 & 53.93 \\
Growth & 4.02 & 0.68 & 70.38 \\
Service & 4.04 & 0.68 & 70.86 \\
HR & 3.68 & 0.6 & 63.52 \\
Trade Union & 2.68 & 1.15 & 43.52 \\
IT & 3.64 & 0.94 & 62.8 \\
Political & 3.59 & 0.64 & 61.84 \\
Obsolescence & 3.36 & 0.79 & 57.24 \\
\multicolumn{1}{c}{ Grand Mean } & $\mathbf{3 . 3 8}$ & & $\mathbf{5 7 . 5 5}$ \\
\hline
\end{tabular}

Per cent Improvement is estimated as below:

The possible performance improvement corresponding to mean 3.04 is calculated as: $50+(3.04-3) * 20=50.74$.

Similarly all other values are calculated.

The mean values of PPI and their corresponding percent improvement are given in columns 2 and 4 respectively. The mean values range from 2.68 to 4.04 and the corresponding percent values are 43.52 and 70.86 ; the grand mean is 3.38 , which is $57.55 \%$. It can be seen that the maximum possible performance improvements (above $70 \%)$ are in "Growth" and "Service" factors. Some other strong areas as per this study are "HR" (63.52\%), "IT" $(62.80 \%)$ and "Political (61.84\%). The modern performance evaluation technique, viz. Balance Score Card (BSC) proposes "Growth and innovation" as one of the major factors for performance improvement. The result obtained in this study indicates that there is much scope for "innovation and modernization" of PSUs of Kerala as the score against "obsolescence" is $57.24 \%$. This result also corresponds to the result of the preliminary study conducted in selected PSUs in Kerala which shows that some organizations make use of obsolete technology producing obsolete products. It implies that there is lot of scope for BPR in PSUs of Kerala, which leads to fundamental restructuring of the organization, and redesigning the product and technology. Further, the executives of such companies see the possibility of $43.52 \%$ improvement in the factor of "Trade Union". These results indicate that, taking all factors of performance together, an average 57.55 percent improvement is possible.

Total PPI (arrived at by adding PPI in 12 individual factors) is found to be 748.13 per cent. This figure may not be accurate as these 12 factors are not independent. Accurate mathematical assessment of the total from these individual factors is beyond the scope of this article. Approximate figures can be assessed using triangulation, using knowledge from other sources. Approximate value is sufficient for the present study as it is intended to assess the scope of BPR implementation.

It is seen from the above analysis that there is high possibility of performance improvements in SPSUs in Kerala. The relationship among various factors of performance improvement can be explained to some extent, by analyzing the correlation between these variables. 


\subsection{Correlation between Factors of Possible Performance Improvement}

The correlation between various factors of performance improvement as per the questionnaire survey among the executives of selected PSUs in Kerala is given in Table 6.

Table 6. Pearson Correlations between Factors of Improvements

\begin{tabular}{|c|c|c|c|c|c|c|c|c|c|c|c|c|}
\hline & $\overrightarrow{0}$ & 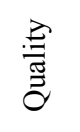 & $\stackrel{\mathscr{\Xi}}{\Xi}$ & $\frac{\overrightarrow{0}}{D}$ & 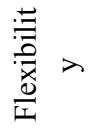 & 产 & 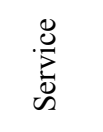 & 寽 & 胥 & $\sqsubseteq$ & : & 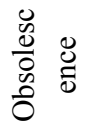 \\
\hline Cost & 1 & .812 & $.886^{* *}$ & $.834^{* *}$ & $.566^{* *}$ & $.449^{* *}$ & $.409^{* *}$ & $.565^{* *}$ & $.595^{* *}$ & $.561^{* *}$ & $.579^{* *}$ & $.481^{* *}$ \\
\hline Quality & & 1 & $.771^{* *}$ & $.732^{* *}$ & $.542^{* *}$ & $.524^{* *}$ & $.525^{* *}$ & $.702^{* *}$ & $.519^{* *}$ & $.641^{* *}$ & $.678^{* *}$ & $.456^{* *}$ \\
\hline Time & & & 1 & $.861^{* *}$ & $.510^{* *}$ & $.413^{* *}$ & $.312^{*}$ & $.452^{* *}$ & $.535^{* *}$ & $.406^{* *}$ & $.458^{* *}$ & $.360^{* *}$ \\
\hline Delivery & & & & 1 & $.440^{* *}$ & $.520^{* *}$ & $.294^{*}$ & $.451^{* *}$ & $.552^{* *}$ & $.452^{* *}$ & $.430^{* *}$ & $.402^{* *}$ \\
\hline Flexibility & & & & & 1 & $.444^{* *}$ & $.349^{* *}$ & $.514^{* *}$ & $.637^{* *}$ & $.527^{* *}$ & $.481^{* *}$ & $.589^{* *}$ \\
\hline Growth & & & & & & 1 & $.410^{* *}$ & $.567^{* *}$ & $.462^{* *}$ & $.409^{* *}$ & $.489^{* *}$ & $.505^{* *}$ \\
\hline Service & & & & & & & 1 & $.686^{* *}$ & .208 & $.629^{* *}$ & $.718^{* *}$ & $.463^{* *}$ \\
\hline HR & & & & & & & & 1 & $.500^{* *}$ & $.674^{* *}$ & $.735^{* *}$ & $.549^{* *}$ \\
\hline $\begin{array}{l}\text { Trade } \\
\text { Union }\end{array}$ & & & & & & & & & 1 & $.382^{* *}$ & $.395^{* *}$ & $.478^{* *}$ \\
\hline IT & & & & & & & & & & 1 & $.675^{* *}$ & $.600^{* *}$ \\
\hline Political & & & & & & & & & & & 1 & $.584^{* *}$ \\
\hline Obsolescence & & & & & & & & & & & & 1 \\
\hline
\end{tabular}

**. Correlation is significant at the 0.01 level (2-tailed).

*. Correlation is significant at the 0.05 level (2-tailed).

The correlation coefficient between cost and quality is found to be 0.812 . The table provides the correlation of all other factors. It is seen that all the factors have high or moderate correlation between each other. It means that the possibility of performance improvements goes together. For example the correlation between time and cost is 0.886. If we reduce time, cost will automatically come down. It can also be seen that improvement due to "political" and "trade union" has a correlation of only 0.395 which shows that the correlation between these factors is low compared to others. It is seen that no pairs have a correlation above 0.9 , which shows that no factor can be excluded. All the correlation estimates, except that between trade union and service, are significant either at 0.05 or at 0.01 .

The significant correlation is an indication that the performance improvement in one factor depends and also contributes to performance improvement in other factors. This is true in practical case also. The present study is aimed at finding the scope of implementation of the drastic performance improvement technique called BPR. Due to multicollinearity, it is difficult to estimate the exact figure of total possible performance improvement in the organization even though we have the possible performance improvement in each factor of performance. Allison (1999) pointed out that when the direction of causation cannot be inferred from data, the decision has to be based on the researcher's knowledge of the subject grounded in theory. The researcher's long experience in a typical PSU of Kerala and connection with many other PSUs can vouch for high PPI in most of the PSUs of Kerala. This is also confirmed by other data and information collected from PSUs under study and interview with employees at various levels in selected PSUs. It can also be seen that in some organizations, for example Automobile company, the present production turnover is one-fifth (150 units) of the installed capacity (750 units) which could be achieved previously without implementing any modern techniques. On implementation of modern techniques, it would certainly increase further. In another company under study, where the researcher was working for long years, the normal monthly production was only one third of normal achievable production. The manpower utilization was only below 50 percent. There was very little computer usage and much scope for 
reduction in material and scrap, quality improvement, and implementation of modern managerial techniques. So there is a potential for high PPI.

This high PPI can also be established by simply analyzing the results of the study. It can be seen that the PPI in political factor is 62 per cent. Figure 1 in the previous section shows the performance of 41 SPSUs during 12 years between 2001-02 and 2012-13. During the period 2001-02 to 2005-06, one political alliance was in power, and during 2006-07 to 2010-11another political alliance was in power. Later, the political situation again reversed. A high difference in performance can be seen during these three periods. From 2001-02 to 2005-06, loss increased from Rs. 2473 lakhs to 8385 lakhs. During the second period, PSUs started making profit. Rs.9012 lakhs profit during 2006-07 increased to Rs.25216 lakhs during 2009-10. During the third period, profit started decreasing. This is a clear evidence of the political factor in PPI. Analyzing other factors of PPI, it can be seen that manpower utilization is very low in most of the organizations; hence there is much possibility of HR factor. Use of IT is rare in PSUs in Kerala; hence there is much scope for PPI due to effective use of IT. Use of IT further improves manpower utilization. In a similar way, all the factors increase PPI in their respective factors and also by synergistic effect, leading the organization to a high per cent of PPI. The results of the study on PPI suggest that high performance improvement is possible in almost all SPSUs in Kerala. Hence there is significant scope for BPR in SPSUs in Kerala.

\subsection{Possibilities of Performance Improvement of SPSUs and CPSUs in Kerala - a Comparison}

Possibility of Performance Improvements in Selected Central PSUs in Kerala is given in table 7. It can be seen that the mean value of performance improvements in various factors for the central PSUs in Kerala varies from 2.67 in the case of quality and 3.61 in the factors of growth and service. The grand mean is 3.22 which correspond to about $54.4 \%$ improvements in each factor of performance.

Table 7. Possibility of Performance Improvements in Central PSUs of Kerala

\begin{tabular}{lccc}
\hline \multirow{2}{*}{ Factors } & \multicolumn{3}{c}{ Central PSUs } \\
\cline { 2 - 4 } & Mean & Standard Deviation & \% Improvement \\
\hline Cost & 3.04 & 0.73 & 50.78 \\
Quality & 2.67 & 0.55 & 43.38 \\
Time & 3.12 & 0.73 & 52.42 \\
Delivery & 3.23 & 0.70 & 54.64 \\
Flexibility & 3.12 & 0.75 & 52.42 \\
Growth & 3.61 & 0.75 & 62.12 \\
Service & 3.61 & 0.97 & 62.12 \\
HR & 3.56 & 0.79 & 61.21 \\
Trade Union & 3.06 & 0.85 & 51.21 \\
IT & 3.50 & 0.92 & 59.94 \\
Political & 3.29 & 0.81 & 55.71 \\
Obsolescence & 2.84 & 0.95 & 46.77 \\
\multicolumn{1}{c}{ Grand Mean } & $\mathbf{3 . 2 2}$ & & $\mathbf{5 4 . 4 0}$ \\
\hline
\end{tabular}

Comparing the possible performance improvements in SPSUs and CPSUs in Kerala, it was seen that average possible improvements in state PSUs are 3.38 and that of Central PSUs is 3.22. The respective percentages are 57.55 per cent and 54.40 per cent. The significance of this difference is tested using paired T-Test. From the results of t-test, it can be seen that the difference in possibility of performance improvement of State and Central PSUs is significant at 0.05 significant level and not significant at 0.01 level. The correlation between the above is 0.842 which is an indication of high correlation between the two, which is significant. It can be interpreted that there are many factors common to State PSUs and Central PSUs, which affect the performance. There are also some differences in performance factors. The correlation value, $r=0.842\left(r^{2}=0.72\right)$ implies that about $0.72 \%$ of the possibility of performance improvements are similar but about $28 \%$ differences also exist. 


\section{Discussion}

The study aimed at identifying the scope for implementing BPR in PSUs of Kerala. Preliminary investigation by analyzing the financial performance of 41 PSUs under the study established that most of the State PSUs are poor performers, and require substantial changes to survive. Twelve factors based on 83 items were identified as major performance improvement factors in PSUs in Kerala. The factors identified and the expected per cent of possible performance improvement as per the opinion of the executives PSUs are:
1. Cost $(50.74 \%)$
2. Quality $(45.80 \%)$
3. Time/Speed $(54.49 \%)$
4. Delivery $(55.47 \%)$
5. Future Growth (70.38\%)
6. Human Resource (63.52\%)
7. Political $(61.84 \%)$
8. Service $(70.86 \%)$
9. Flexibility $(53.93 \%)$
10. Trade Union $(43.52 \%)$
11. Information Technology (62.80\%)
12. Obsolescence (57.24\%).

It can be inferred that there is a high possibility of drastic performance improvements in all PSUs under study. Evaluating the possibility of performance improvement using other methods also confirms the results.

Comparing the possible performance improvements in SPSUs with that of CPSUs in Kerala, it is seen that average possible improvements in state PSUs is 57.55 and that of Central PSUs is 54.40, and the significance of this difference is 0.045 . The correlation value of the possible performance improvements in State and Central PSUs is 0.842 showing significant correlation. These results show that the possibility of performance improvements in PSUs, whether under state or under central, are similar even though there are differences in some factors. Hence it is concluded that there is much potential for improvement in performance by adopting BPR in PSUs in Kerala, both central and state PSUs. The estimated average possible performance improvement of $57.55 \%$ in twelve factors of performance in this study is comparable to the performance improvements achieved in the studies of Irani \& Zairi (2001) and Thong, Yap and Seah (2000). The average performances in those studies were $63 \%$ and $62.4 \%$ respectively.

\section{Conclusions}

The scope for implementation of BPR in PSUs of India is established in the present study. It also estimates that more than 50 percent improvement is possible in the 12 performance factors. From the study, it was also seen that performance factors differ from organization to organization. The study is thus a pointer to the need for a further detailed study aimed at designing an appropriate firm specific project for implementing BPR. Apart from being an indicator for application of BPR on poorly performing PSUs in a developing country, the present study also contributes to BPR theory by identifying additional factors of performance improvement.

\section{References}

Allison, P. D. (1999). Multiple regressions: A primer. Thousand Oaks, CA: Pine Forge Press.

Al-Mashari, M., Irani, Z., \& Zairi, M. (2001). Business process reengineering: A survey of international experience. Business Process Management Journal, 7(5), 437-455. http://dx.doi.org/10.1108/1463715011 0406812

Altinkemer, K., Ozcelik, Y., \& Ozdemir, Z. D. (2011). Productivity and Performance Effects of Business Process Reengineering: A Firm-Level Analysis, Journal of Management Information Systems, 27(4), 129-161. http://dx.doi.org/10.2753/mis0742-122227040

Altman, E. I., Haldeman, R. G., \& Narayanan, P. (1977). Zeta Analysis A New Model to Identify Bankruptcy Risk of Corporations. Journal of Banking \& Finance, 1(1), 29-54. http://dx.doi.org/10.1016/0378-4266 (77)90017-6

Antony, M. T. (1992). Efficiency in Central Public Sector Enterprises in Kerala: An Analysis of Capacity Utilization, Profitability and Productivity (Doctoral dissertation). Cochin University of Science and Technology, Cochin, India. Retrieved from http://shodhganga.inflibnet.ac.in:8080/

Attaran, M. (2004). Exploring the relationship between information technology and business process reengineering. Information \& Management, 41(5), 585-596. http://dx.doi.org/10.1016/s0378-7206(03)00 098-3

Bhatt, G. D., \& Troutt, M. D. (2005). Examining the relationship between business process improvement initiatives, information systems integration and customer focus: an empirical study, Business Process Management Journal, 11(5), 532-558. http://dx.doi.org/10.1108/14637150510619876

Chung, Y. C., Hsu, Y. W., \& Yen, T. M. (2008). Using the Six Sigma System approach to Reduce Core Process 
Times at a Manufacturing Plant. International Journal of Management, 25(3), 431-438. ABI/INFORM Global, pg.431.

Davenport, T. H., \& Short, J. E. (1990). The New Industrial Engineering: Information Technology and Business Process Redesign. Sloan Management Review, 31(4). ABI/INFORM Global.

Elzinga, D. J., Horak, T., Lee, C. Y., \& Bruner, C. (1995). Business Process Management: Survey and Methodology. IEEE Transations of Engineering Management, 42(2), 119-128. http://dx.doi.org/10.1109/17. 387274

Garzon, I. E. (2000). Optimization for Product and Process Improvement: Investigation of Taguchi Tools and Genetic Algrithms (Unpublished doctoral dissertation). University of Newcastle Upon Tyne.

Goel, S., \& Chen, V. (2008). Integrating the global enterprise using Six Sigma: Business process reengineering at General Electric Wind Energy. International Journal of Production Economics, 113(2), 914-927. http://dx.doi.org/10.1016/j.jpe.2007.12.002

Goksoy, A., Ozsoy, B., \& Vayvay, O. (2012). Business Process Reengineering: Strategic Tool for Managing Organizational Change an Application in a Multinational Company. International Journal of Business and Management, 7(2), 89-112. http://dx.doi.org/10.5539/ijbm.v7n2p89

Government of Kerala (1995 to 2013). A review of public enterprises in Kerala (1994-95 to 2012-13). Bureau of Public Enterprises, Thiruvananthapuram.

Government of Kerala (2005). MGP: II.2.1, State level public enterprises reform: implementation of SLPE reform. Retrieved from www.old.kerala.gov.in/archive/221.pdf

Hammer, M. (2002). Process management and the future of six sigma. Sloan Management Review, 43(2), 26-32. http://dx.doi.org/10.1109/emr.2002.1167284

Hammer, M., \& Champy, J. (1993). Reengineering the corporation: A manifesto for business revolution. Harper Collins, New York.

Hammer, M., \& Champy, J. (2001). Reengineering the corporation: A manifesto for business revolution. New York, Harper Collins.

Hammer, M., \& Stanton, S. A. (1995). The reengineering revolution. Harper Collins, New York.

Herzog, N. V., Polajnar, A., \& Tonchia, S. (2007). Development and validation of business process reengineering (BPR) variables: a survey research in Slovenian companies. International Journal of Production Research, 45(24), 5811-5834. http://dx.doi.org/10.1080/00207540600854992

Kanungo, S., Sadavarti, S., \& Srinivas, Y. (2001). Relating IT strategy and organizational culture: an empirical study of public sector units in India. Journal of Strategic Information Systems, 10, 29-57. http://dx.doi.org/10.1016/s0963-8687(01)00038-5

Kareem, E. (2011). Resurgence of state level public enterprises: The Kerala experiences. International workshop on Kerala studies, Trivandrum, January 1-3.

Kim, K. H., \& Kim, Y. G. (1997). Process reverse engineering for BPR: A form-based approach. Information \& Management, 33, 187-200. http://dx.doi.org/10.1016/s0378-7206(98)00027-5

Kondareddy, S. (1998). From business process reengineering to integrated process management: An exploration of issues (Doctoral Thesis). Purdue University, Available from ProQuest Dissertations and Theses, ABI/INFORM Global.

Kuwaiti, M. E. (2000). The Role of Performance Measurement Systems in the Design and Implementation of Business Process Re-Engineering (Doctoral Thesis). Cranfield University. Available from ProQuest Dissertations and Theses, ABI/INFORM Global.

Macintosh, R. (2003), BPR: Alive and well in the public sector. International Journal of Operations \& Production Management, 3(23), 327-344. http://dx.doi.org/10.1108/01443570310462794

Mathew, G., Sulphey, M. M., \& Rajasekar, S. (2014). Organizational Performance and Readiness for Change of Public Sector Undertakings. African Journal of Business Management, 8(19), 852-863. http://dx.doi.org/10.5897/ajbm2014.7520

Mathew, V. (1997). Performance Evaluation of State Public Enterprises in the Manufacturing Sector of Kerala (Doctoral dissertation). Cochin University of Science and Technology, Cochin. Retrieved from http://shodhganga.inflibnet.ac.in:8080/ 
Mazany, P. (1995). A case study: Lessons from the progressive implementation of just-in-time in a small knitwear manufacturer. International Journal of Operations \& Production Management, 15(9), 271-288. http://dx.doi.org/10.1108/01443579510099788

Nandan, S., \& Varma, A. (2013). Organizational change effectiveness in Indian public sector organizations: perceptions of employees at different levels. South Asian Journal of Management, 20(1), 97-113. Retrieved from http://web.a.ebscohost.com/

Paper, D. J., Rodger, J. A., \& Pendharker, P. C. (2001). A BPR case study at Honeywell, Business Process Management Journal, 7(2), 85 -99. http://dx.doi.org/10.1108/14637150110389416

Radhakrishnan, R, \& Balasubramanian, S. (2008). Business Process Reengineering: Text and Cases. Prentice-Hall of India Private Ltd., New Delhi.

Rahimi, A. (1996). Development of a Methodology for the Effective Implementation of Business Process Reengineering in Manufacturing Companies (Doctoral Thesis). Loughborough University of Technology. Retrieved from https://dspace.lboro.ac.uk/dspace-jspui/bitstream/2134/7428/3/Thesis-1006-Rahimi.pdf

Ranganathan C., \& Dhaliwal, J. S. (2001). A Survey of Business Process Reengineering Practice in Singapore. Information \& Management, 39, 125-134. http://dx.doi.org/10.1016/s0378-7206(01)00087-8

Rinaldi, M, Montanari, R., \& Bottani, E. (2015) Improving the efficiency of public administrations through business process reengineering and simulation: A case study. Business Process Management Journal, 21(2), 419-462. http://dx.doi.org/10.1108/BPMJ-06-2014-0054

Schacter, M. (2000). Public Sector Reform in Developing Countries: Issues, Lessons and Future Directions. Institute on Governance, Ottawa, Canada. Retrieved from http://citeseerx.ist.psu.edu/viewdoc/ download?doi=10.1.1.473.7078

Siha, S. M., \& Saad, G., H. (2008). Business process improvement: empirical assessment and extensions. Business Process Management Journal, 14(6), 778-802. http://dx.doi.org/10.1108/14637150810915973

Thong, J. Y. L., Yap, C. S., \& Seah, K. L. (2000). Business Process Reengineering in the Public Sector: The Case of the Housing Development Board in Singapore. Journal of Management Information Systems, 245-270. Retrieved from http://hdl.handle.net/1783.1/24583

Womack, J. P., \& Jones, D. T. (1996). Beyond Toyota: how to root out waste and pursue perfection. Harvard Business Review, September-October, 140-158. Retrieved from https://hbr.org/1996/09/how-to-root-outwaste-and-pursue-perfection

Yung, W. K., \& Chan, D. T. (2003). Application of value delivery system (VDS) and performance benchmarking in Flexible Business Process Reengineering. International Journal of Operations \& Production Management, 23(3), 300-315. http://dx.doi.org/10.1108/014435703104622776

Zaheer, A., Rehman, K. U., \& Saif, M. I. (2008). Development and testing of business process efficiency scale. European Journal of Social Sciences, 7(2). Retrieved from http://mpra.ub.uni-muenchen.de/54467/

\section{Copyrights}

Copyright for this article is retained by the author(s), with first publication rights granted to the journal.

This is an open-access article distributed under the terms and conditions of the Creative Commons Attribution license (http://creativecommons.org/licenses/by/3.0/). 